Abstracta Iranica Abstracta Iranica

Revue bibliographique pour le domaine irano-aryen

Volume 28 | 2007

Comptes rendus des publications de 2005

\title{
"Changes in the Oral Tradition of the Yezidis of Iraqi Kurdistan ». Journal of Kurdish Studies, V, 2005, pp. 73-83.
}

\section{Christine Allison}

\section{(2) OpenEdition}

Journals

Édition électronique

URL : http://journals.openedition.org/abstractairanica/12272

DOI : 10.4000/abstractairanica.12272

ISSN : 1961-960X

Éditeur :

CNRS (UMR 7528 Mondes iraniens et indiens), Éditions de l'IFRI

\section{Édition imprimée}

Date de publication : 15 mai 2007

ISSN : 0240-8910

Référence électronique

Christine Allison, " "Changes in the Oral Tradition of the Yezidis of Iraqi Kurdistan ». Journal of Kurdish Studies, V, 2005, pp. 73-83. », Abstracta Iranica [En ligne], Volume 28 | 2007, document 255, mis en ligne le 18 septembre 2007, consulté le 25 septembre 2020. URL : http://journals.openedition.org/ abstractairanica/12272 ; DOI : https://doi.org/10.4000/abstractairanica.12272

Ce document a été généré automatiquement le 25 septembre 2020.

Tous droits réservés 


\title{
«Changes in the Oral Tradition of the Yezidis of Iraqi Kurdistan $»$. Journal of Kurdish Studies, V, 2005, pp. 73-83.
}

\author{
Christine Allison
}

1 This article reflects the complexities and challenges of fieldwork experience amongst Yezidis in Iraq, whose faith is undergoing major changes. In the village and tribal environment of the past, traditional Yezidism was transmitted orally and its traditions were profoundly influenced by processes of non-literate composition, teaching and learning, and by the practical needs of the community. Yezidi religious experts have always been few and are now fewer, due to 'TV culture' which undermines folklore in general. Moreover the transition to higher levels of literacy has produced an unqualified respect for the written source by comparison with the oral and consequent canon formation and 'scripturalisation'. The general process of re-evaluation of the religion also comprises many attempts to modernise mythology to make it more 'scientific', to reject Islamic elements in the belief system and in texts, and to search for non-Islamic origins. These attempts to make Yezidism more acceptable to those with a 'modern' world-view (and also to outsiders) are bringing about a radical transformation.

\section{INDEX}

Thèmes : 6.3. Autres religions 
AUTEURS

CHRISTINE ALLISON

INaLCO / Mondes iranien et indien - Paris 